\title{
Arabic Studies in the Netherlands and the Prerequisite of Social Impact - a Survey
}

\author{
Arnoud Vrolijk
}

On 14 May 1613 Thomas Erpenius (1584-1624) accepted his nomination as the first professor of Arabic at Leiden by pronouncing his inaugural address 'On the Excellence and Dignity of the Arabic Language'1 (Figure 1.1). In 2013 the fourth centenary of Arabic studies was celebrated with a great variety of activities. $^{2}$ A tradition of 400 years in one single discipline is a long time by any standard, especially if one realizes that the University, founded in 1575 , is not much older than that itself. Yet few people know that Arabic is the only language to have been taught almost continuously at Leiden apart from Latin, Greek and Biblical Hebrew. Dutch made its first appearance in the late eighteenth century; modern languages such as English, French and German only followed suit in the course of the nineteenth century. The Classics and Biblical Hebrew, however, were all extinct languages, even though Neo-Latin played an important role in scholarly communication. Moreover, Latin, Greek and Hebrew were traditionally regarded as the pillars of our own culture and religion. Arabic, on the other hand, was not only a living language, but also the vehicle of an alien culture which was very much alive, literally exotic and often

1 T. Erpenius, Oratio de lingvae Arabicae praestantia et dignitate, dicta in Illvstri Batavorvm Academia mense Maio M.D.CXIII. Cum ejus Linguae, et aliarum Orientalium Professionem auspicaretur, printed Leiden, 1615 or later.

2 Between September 2013 and March 2014 an exhibition on 400 years of Arabic studies in the Netherlands was held at the National Museum of Antiquities (Rijksmuseum van Oudheden, RMO), Leiden, mainly with materials from the special collections of Leiden University Libraries [<http://www.rmo.nl/english/exhibitions/archive/excellence-anddignity>, accessed 21 Nov 2016]. Simultaneously, a book on the same subject was published: A. Vrolijk and R. van Leeuwen, Voortreffelijk en Waardig: 4oo jaar Arabische studies in Nederland, Leiden 2012. An English translation by A. Hamilton was published under the title: A. Vrolijk and R. van Leeuwen, Arabic Studies in the Netherlands: a Short History in Portraits, 1580-1950, Leiden, 2014. Both the book and the publications were part of the HERA project 'Encounters with the Orient in Early Modern European Scholarship', coordinated by Professor Charles Burnett and Dr Jan Loop of the Warburg Institute, University of London. A supplementary grant was kindly awarded by Saudi Aramco, Dhahran, Saudi Arabia. Many other activities were undertaken by the Department of Middle East Studies of the University of Leiden. 


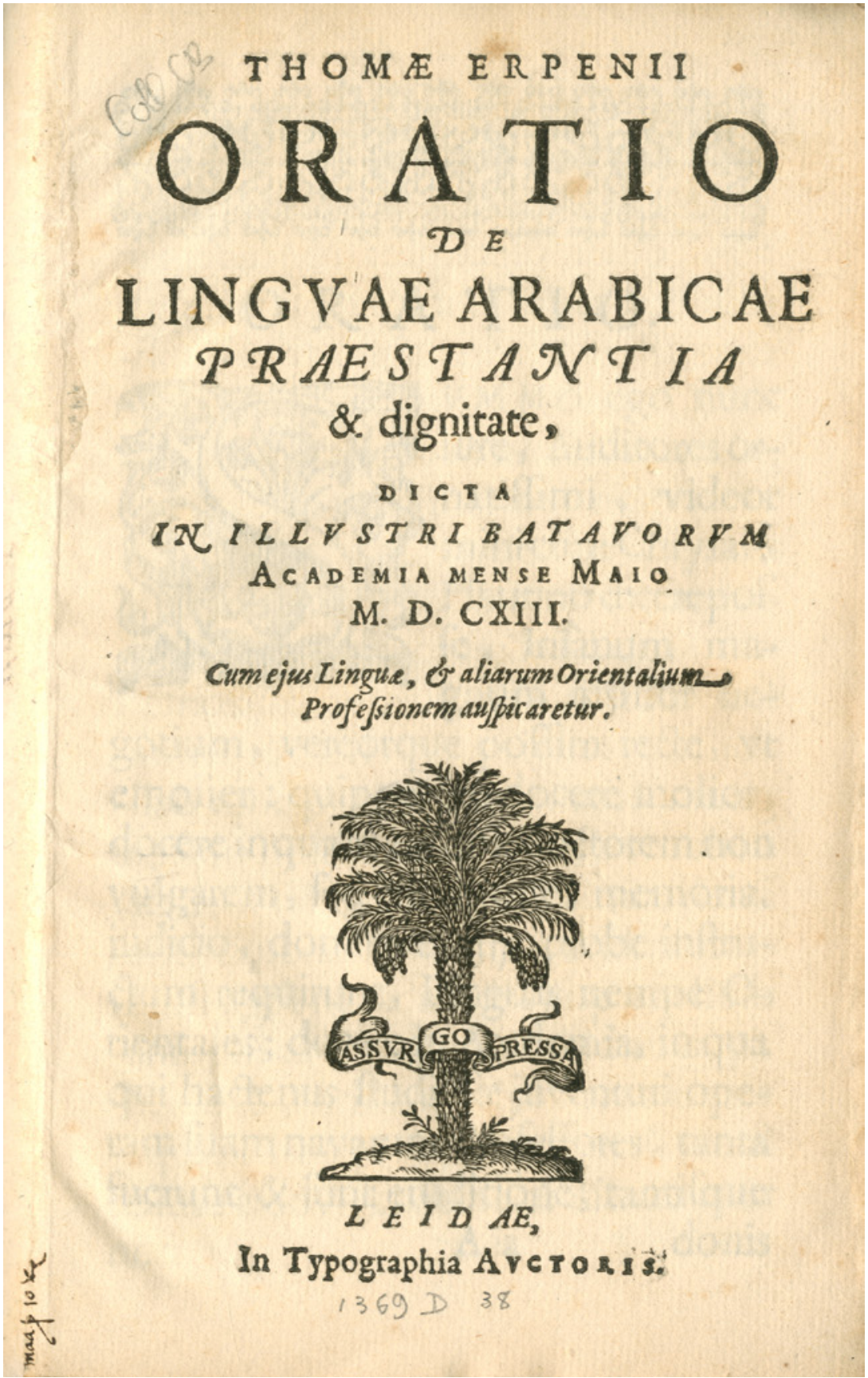

FIGURE 1.1 Oration of Thomas Erpenius (1584-1624) on the Excellence and Dignity of the Arabic language', May 1613 (printed Leiden, 1615 or later), title page. [LEIDEN UNIVERSITY LIBRARIES, 1369 D 38] 
hostile. And especially because of its longevity, the history of Arabic studies provides an enormous amount of information on how Dutch scholars observed and studied a culture that was, and still is, not their own. In spite of the impressive achievements of individual scholars, the results are not unequivocally positive.

\section{Social Impact}

The first observation to be made is that Dutch Arabists have generally followed the current of Western scholarship. In the age of Humanism they were humanists, during the Enlightenment they were enlightened, in the days of Auguste Comte they were positivists, and so on. Typically, their scholarly enquiries did not drastically change their outlook or methodology, or cause them to go against the flow. Of much greater importance is the fact that Arabic studies in the Netherlands have always had a strongly apologetic character, not only visà-vis the Arab world or Islam, but also with regard to the home front. Arabic always had to be accounted for, then as well as now. Whenever a student says that he reads Arabic the question will invariably be 'why?'. No one will ever say that to a student of English or French. Dutch academics have always been free to study the plays of Shakespeare, the essays of Montaigne or the novels of Tolstoy without jeopardizing their respectability, but the scholar who reads pre-Islamic poetry will usually be asked for a reason. Unwilling to spend public money on frivolous subjects, Dutch society has always attached a price to the study of Arabic which was called 'utilitas' in the seventeenth century and 'social impact' in modern times. In the Netherlands this is now mostly a financial calculation, where public expenditure on higher education is balanced against the short-term effects on the national economy. One will generally find the arguments enumerated in the inaugural addresses of the professors from the earliest period onwards - the importance of combating Islam with the force of arguments, or converting Muslims to Protestant Christianity. Of equal importance was the use of Arabic as an aid for learning Hebrew, which led to the nickname of Arabic as ancilla theologiae, 'the handmaiden of theology'. The demand for Arabic texts on the exact sciences, such as astronomy, medicine or mathematics, slackened after the seventeenth century, when the gap between the two scientific traditions had been bridged.

The 'utilitas' of Arabic studies has always been very much apparent in the diplomatic and economic relations between the Netherlands and the Islamic world. In 1612 Sultan Ahmed I of the Ottoman Empire concluded a treaty of peace and friendship with the Dutch Republic, whereby the Dutch merchants 
obtained the right to trade with the Ottoman Empire under very favourable conditions. ${ }^{3}$ The interests at stake were large, amounting to millions of guilders. They concerned the import of luxury goods, but first and foremost textiles. David Le Leu de Wilhem (1588-1658), for example, was a Levant merchant, statesman and patron of Oriental scholarship. He travelled to Egypt as part of his Grand Tour and there acquired Egyptian antiquities, not only smaller objects such as shabtis and canopes, but also a large mummy. After his return he donated these objects to the cabinet of curiosities of Leiden University, which was part of the anatomical theatre on the upper floor of the former Faliede Bagijnkerk (Beguinage Church) on the Rapenburg canal. On an engraving from 1712 the lid of the sarcophagus can clearly be seen, standing on top of a display cabinet in the far right corner (Figure 1.2) $\cdot{ }^{4}$ In 1821 most of the Egyptian antiquities of De Wilhem were transferred to the newly founded National Museum of Antiquities in Leiden; the sarcophagus followed in 1872 . De Wilhem embarked on a career in the Levant, where he was active in the textile trade. In 1629 he returned to the Dutch Republic and rose to high positions in the bureaucracy in The Hague. He never went back to the Middle East, but he never forgot his past career. He gave financial support to young scholars who wanted to travel to the Levant, such as the German student Levinus Warner (c. 1618-1665), who studied Oriental languages in Leiden under Jacobus Golius. In December 1644 Warner left for Istanbul with a travel grant from De Wilhem. He lived in Istanbul for twenty years, eventually obtaining the position of 'resident' or envoy of the Dutch Republic to the Sublime Porte. In his leisure time he assembled an important private collection of about a thousand Oriental manuscripts. Warner never came back to Western Europe: he died in Istanbul in 1665, leaving his manuscript collection to Leiden University, where he had once been a student. Thus De Wilhem was instrumental in the acquisition of the early collections of both the University of Leiden and the Museum of Antiquities. ${ }^{5}$

3 On the Capitulations granted by Sultan Ahmed I see A.H. de Groot, The Ottoman Empire and the Dutch Republic: A History of the Earliest Diplomatic Relations, Leiden-Istanbul, 1977.

4 Les délices de Leide: Qui contiennent une description exacte de son antiquité, de ses divers aggrandissemens, de son académie, de ses manufactures, de ses curiosités ..., le tout enrichi de tailles douces, Leiden, 1712, ill. no. 8 facing p. 83 .

5 On David de Wilhem and his Egyptian collection see Leidse Universiteit 4oo. Stichting en eerste bloei, 1575-ca. 1650, Amsterdam, 1975, pp. 113-15; A. Vrolijk, 'Voortreffelijk en Waardig. 400 jaar Arabische studies in Nederland', RMo Magazine: Uitgave van de Vriendenvereniging van het Rijksmuseumvan Oudheden, 14, 2013, no. 36, pp. 38-42. On Levinus Warner see W.M.C. Juynboll, Zeventiende-eeuwsche beoefenaars van het Arabisch in Nederland, Utrecht, 1931, pp. 222-34; A. Vrolijk, J. Schmidt and K. Scheper, Turcksche Boucken: The Oriental Collection of Levinus 


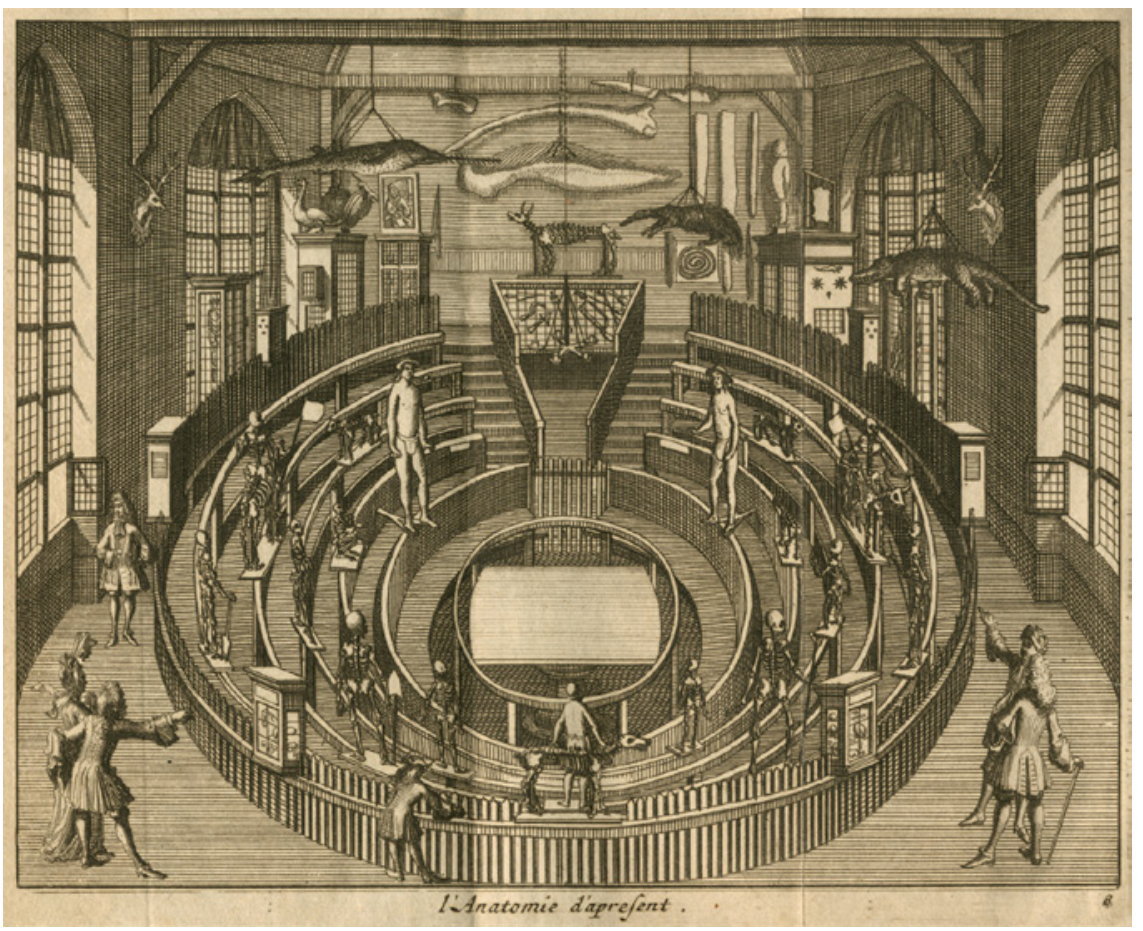

FIGURE 1.2 The cabinet of curiosities of Leiden University, with in the far right corner an Egyptian mummy donated by David Le Leu de Wilhem (1588-1658). Les delices de Leide ..., Leiden, 1712, facing p. 83. [LEIDEN UNIVERSITY LIBRARIES, 403 G 15]

In the last decade of the sixteenth century the Dutch also gained access to Muslim Southeast Asia, a rich source of spices, which were sold in Holland at an enormous profit. Understandably, the Dutch mercantile aristocracy was relatively uninterested in stressing the theological differences between believers and infidels.

The intellectual stronghold of the same merchant élite was the University of Leiden. In this light it is hardly surprising that at a very early stage efforts should have been undertaken to give Arabic a place on the curriculum with a keen eye on business interests. The governors of the young University, all without exception politicians and merchants, were well aware that Arabic served as the lingua franca of the Muslim world. In August 1599 they granted permission

Warner, Dutch Diplomat in Seventeenth-Century Istanbul, Eindhoven, 2012; Vrolijk and van Leeuwen, Arabic Studies, pp. 48-59. 
to Philippus Ferdinandus, a Jewish convert from Poland, ${ }^{6}$ to teach Arabic for a trial period with the explicit argument that it would be useful for the East Indian trade. In their deliberations the gentlemen of the Board assumed that 'the Arabic tongue is much used in those parts.' Indeed, early Arabists such as Franciscus Raphelengius (1539-1597) and Joseph Justus Scaliger (1540-1609) performed translation services for the States General in The Hague, a tradition which would continue until the early nineteenth century. ${ }^{8}$

Later in the seventeenth century the symbiosis between economy, politics and Arabic studies fully emerged in the person of Jacobus Golius (1596-1667), the second professor of Arabic at Leiden from 1625 onwards. Golius, whose father was a high-ranking official of the Council of State (Raad van State) in The Hague, took advantage of the new diplomatic network of the Dutch Republic and travelled to Morocco on a diplomatic mission in the early $1620 s$. Not long afterwards, in 1625 , he journeyed to the Ottoman Empire, where he worked at the Dutch consulate in Aleppo and the embassy in Istanbul and acquired Oriental manuscripts, both for the University and his private library. ${ }^{9}$

The eighteenth century was a period of relative economic and political decline for the Netherlands, and in this era the gain from Arabic was mainly immaterial or spiritual. The chief protagonist of Arabic studies at Leiden was Albert Schultens (1686-1750), who was professor of Oriental languages from 1729 to $1749 .{ }^{10}$ Schultens's career was wholly dedicated to philologia sacra, the 'sacred philology' of the Bible. In order to explain the Hebrew of the Old Testament, Schultens had recourse to Arabic, which he came to regard as a 'twin sister of Hebrew' more perfectly preserved in the isolation of the desert.

6 On Philippus Ferdinandus see A. Hamilton, 'Ferdinand, Philip (1556-1599)', ODNB, 2004, online edn [<http://www.oxforddnb.com/view/article/9308>, accessed 21 Nov 2016].

7 'dat die Arabische spraecke [...] aldaer veel gebruyct wort'. See P.C. Molhuysen, Bronnen tot de geschiedenis der Leidsche universiteit, 7 vols, The Hague, 1913-1924, 1, pp. 120-22, 404*-06*; Vrolijk and Van Leeuwen, Arabic Studies, p. 30.

H. de Leeuw, 'The First Dutch-Indonesian Treaty: A rediscovered Arabic Translation by Franciscus Raphelengius', Manuscripts of the Middle East, 4, 1989, pp. 115-22; A. Vrolijk, 'Scaliger and the Dutch Expansion in Asia: An Arabic Translation for an Early Voyage to the East Indies (160o)', Journal of the Warburg and Courtauld Institutes, 78, 2015, pp. 277309 .

9 On Golius see Juynboll, Beoefenaars, pp. 119-83; Vrolijk and Van Leeuwen, Arabic Studies, pp. 41-8.

10 On Albert Schultens see J. Nat, De studie van de Oostersche talen in Nederland in de 18e en de rge eeuw, Purmerend, 1929, pp. 37-63; J. Loop, 'Kontroverse Bemühungen um den Orient: Johann Jakob Reiske und die deutsche Orientalistik seiner Zeit', in Johann Jakob Reiske: Leben und Wirkung: Ein Leipziger Byzantinist und Begründer der Orientalistik im 18. Jahrhundert, eds H.G. Ebert and T. Hanstein, Leipzig, 2008, pp. 45-85; Vrolijk and Van Leeuwen, Arabic Studies, pp. 73-9. 
As such, the role of Arabic as the 'handmaiden of theology' was very much a social one, since Arabic was instrumental in the exegesis of the Bible in a country where God's Word, as preached by the ministers of the Calvinist faith, controlled the minds and morals of Society to a very large extent. Until the 1870 it was perfectly normal for Protestant ministers to have a smattering of Arabic and the other 'dialects' of Biblical Hebrew, and many Dutch Arabists started out as students of theology, or were the sons of clergymen.

The Napoleonic wars and their aftermath inflicted heavy damage on the Dutch economy in the first half of the nineteenth century, but this changed for the better in the era of Imperialism. An example is the textual scholar Michael Jan de Goeje (1836-1909), mainly known as the driving force behind the edition of the Annals of al-Tabari, the largest Arabic text ever to have appeared in metal-type print in the western world and published by the Leiden firm of E.J. Brill. ${ }^{11}$ But in 1866, eight years after the discovery of the sources of the Nile by John Hanning Speke, even a good-natured philologist such as De Goeje was infected by the spirit of Imperialism and the role which ancient Arabic geographical texts might play in the exploration and colonization of darkest Africa:

Is it still necessary [...] to illustrate what those books have to teach us? Or how useful the knowledge which the Arabs have gained about North Africa, the Sahara and the land of the Negroes, has been to European travellers, and still is? And how helpful the experience of the Arabs could be if Europe wanted to carry its civilizing influence deep into Asia and Africa? ${ }^{12}$

The social relevance of Arabic, however, found its culmination in the person of the controversial Arabist and Islam scholar Christiaan Snouck Hurgronje (1857-1936) who, after having travelled to Mecca in 1884-1885, became an adviser on indigenous and Muslim affairs in the Dutch East Indies and a key

11 On Michael Jan de Goeje see Vrolijk and Van Leeuwen, Arabic Studies, pp. 103-13.

12 M.J. de Goeje, De belangrijkheid van de beoefening der Arabische taal en letterkunde: Redevoering ter aanvaarding van het hoogleeraarsambt aan de hoogeschool van Leiden, den 6den October 1866 uitgesproken, 's Gravenhage, 1866, pp. 16-17: 'Zou het noodig zijn [...] nog toe te lichten, wat voor ons uit die boeken te leeren is? Van hoeveel nut de kennis, die de Arabieren van Noord-Africa, van de Sahara en het land der Negers hadden, voor de Europeesche reizigers reeds geweest is, en nog is? Welken steun hunne ervaring zal kunnen geven, als Europa zijn beschavenden invloed tot diep in Azië en Africa zal willen doen doordringen?'; Vrolijk and Van Leeuwen, Arabic Studies, p. 110. 
player in Dutch colonial policy. ${ }^{13}$ In 1906 he returned from Batavia to Leiden, where he was appointed professor of Arabic. According to Snouck Hurgronje, social impact was the raison d'être of Arabic studies. He reduced Arabic to the status of an ancillary science to Islamic studies, and Islamic studies to a tool for the ideological and political control of the Dutch East Indies. His inaugural address as professor of Arabic in 1907 explained this in no uncertain terms:

The study of the Arabic language and of the spiritual life [i.e. Islam, A.V.] whose vehicle it has become is an important part of the study of human history. But on us, as Dutchmen, it has an even greater claim since thirty million of our fellow subjects of the Queen of the Netherlands take part, in their own way, in this spiritual life. ${ }^{14}$

At the end of his address he even expressed the hope that he should never forget that Arabic covered far more than Islam. It is probably a unique instance in the history of universities of a professor who, on the threshold of his assignment, hopes he will not forget to do his job - which is, incidentally, precisely what he did, for both his tuition and research remained strictly limited to colonial Islam. ${ }^{15}$

After the Second World War and Indonesian independence the winds changed. In an era of unprecedented economic prosperity and intellectual freedom in the Netherlands, scholars started to pay serious attention to Arabic language and culture. Suddenly, the question became relevant of whether the Arabs had written any good books, or composed beautiful music, or produced fine art? In addition to the traditional stronghold of Leiden, chairs of Arabic were founded at the universities of Amsterdam (UvA), Utrecht and Nijmegen. As protagonists in Leiden we have Jan Brugman, who studied modern Arabic literature in Egypt, and his successor Remke Kruk, who specialized in the transmission of Greek science to the Muslim world and thence to the West, popular epic, magic, medieval botany and zoology. Manfred Woidich and Kees

13 Literature on Christiaan Snouck Hurgronje is too vast to be mentioned in any detail; for a general overview see Vrolijk and Van Leeuwen, Arabic Studies, pp. 117-50.

14 C. Snouck Hurgronje, Arabië en Oost-Indië: Rede bij de aanvaarding van het hoogleeraarsambt aan de Rijks-Universiteit te Leiden, den 23sten Januari 1907, Leiden, 1907, p. 5: 'De studie van de Arabische taal en van het geestelijk leven, welks voertuig zij geworden is, vormt een gewichtig onderdeel van de wetenschap der menschelijke geschiedenis. Zij heeft echter meer dan gewone aanspraak op de toewijding van ons, Nederlanders, daar dertig millioenen onzer mede-onderdanen van Nederlands Koningin op hunne wijze aan dat geestelijk leven deelnemen.' Ibid., p. 25; Vrolijk and Van Leeuwen, Arabic Studies, p. 134. 
Versteegh, of the universities of Amsterdam and Nijmegen, were, respectively, eminent scholars of modern Egyptian dialects and Classical Arabic grammar.

Now, in 2015, all this has changed. The shifting priorities of public expenditure are deeply felt in an area of the humanities which has always been highly dependent on Government funding. Add to this the events of ' $9 / 11$ ' and the political preoccupation with radical or extremist Islam and one will understand why most of these Arabic chairs have been discontinued or merged with Islamic studies. As a result, Arabic has been reduced to the role of the 'handmaiden of theology' once again. It is of course understandable that the Government should be reluctant to spend tax money on a professor who investigates modern Egyptian dialects while a large part of the Arab world is in turmoil, but the pressure of contemporary politics and the economic imperative will inevitably result in blurring our view of Arab culture. There will also be the risk of losing touch with scholarship in the Arab world, where there is still an avid interest in the tradition of poetry, art, manuscripts and the like, even in the present period of adversity.

Currently Leiden is the only remaining university in the Netherlands with a chair of Arabic language and culture. But even at Leiden University the islamization' of Arabic scholarship and the prerequisite of social impact cannot be avoided. On the Dies natalis (anniversary) of the University in February 2013, honorary doctorates were awarded on the occasion of the fourth centenary of Arabic studies to professors Patricia Crone and Michael Cook (Princeton), who are highly critical historians of early Islam rather than specialists in the fields of Arabic belles lettres or linguistics, let alone art, theatre, music, philosophy or even cookery. This choice of laureates is hardly surprising, given the present focus of the department of Middle Eastern Studies on the origins and early history of Islam, an interest they share with most Salafi Muslims, but for entirely different reasons.

The same conditions of social impact appear to apply to external funding. When preparing an exhibition and the accompanying books on the history of Arabic studies in the Netherlands, I quite naturally turned to a large grant-giving body with close ties to the University, whose name I am not at liberty to reveal. My application was rejected, however, with the argument that 'the Committee had given priority to proposals with social impact'. ${ }^{16}$ This is ironic, because until recently the organization had its premises in the former home of Christiaan Snouck Hurgronje. For all practical purposes it would appear that de voorkeur gegeven aan projecten met maatschappelijke relevantie.' 
the ghost of Snouck, the champion of social impact in Arabic studies, is still haunting his rambling patrician mansion.

\section{Popular Discourse and Islam}

Yet it would hardly be fair to characterize the Dutch Arabists as mere pawns in a play of economics, politics and religion. Though remaining staunchly antiIslamic, in any case until the mid-nineteenth century, their knowledge of Arabic enabled them, in their own limited way, to communicate with Muslims, if not by going to the Middle East themselves, then at least by reading the written sources. As a result, their knowledge has in many instances led to a certain amount of tolerance and understanding. This relative understanding becomes all the more apparent if one compares it with the dominant popular discourse on Arabs and Islam in the Netherlands. An example of the latter is an anonymous treatise which appeared in Amsterdam in 1627 under the title Historie van den Oorspronck, Geslacht, Geboorte, Opvoedinge, en Leere des grooten valschen Propheets Mahomets ('History of the Origin, Descent, Birth, Education and Teachings of the Great False Prophet Mahomet'). ${ }^{17}$ Not based on any serious research, it recycled the ancient accounts of Muhammad as a fraud and an epileptic which first appeared in their most rudimentary form in Byzantine sources from the mid-eighth century AD onwards. ${ }^{18}$ Far more elaborate stories about the Prophet and his alleged medical condition, however, have circulated in the Latin West since the early twelfth century in the works of authors such as Embrico of Mainz and Gautier of Compiègne. In these accounts the Prophet

17 [Anonymous], Historie van den Oorspronck, Geslacht, Geboorte, Opvoedinge, en Leere des grooten valschen Propheets Mahomets, Alsmede / hoe hy sijn Secte onder de Menschen gestroyt, en van die aengenomen is / en wat eynde hy selfs genomen heeft ..., Amsterdam, 1627 (2nd edn 1640).

18 The earliest surviving Byzantine source, De Haeresibus Liber of John of Damascus (d. ca. $\left.75^{\circ} \mathrm{AD}\right)$, calls Muhammad only a 'pseudoprophet' and a fraud; the second source, the Chronographia of Theophanes Confessor (d. 818) is apparently the first to ascribe a mental disease to the Prophet by calling him an epileptic; the third source, Opuscula Islamica by Theodore Abū Qurra (d. between 820 and 825), calls him 'possessed by demons' and 'mad'. See D.J. Sahas, John of Damascus on Islam: The 'Heresy of the Ishmaelites', Leiden, 1972, pp. 74-5 (see p. 75 n. 1 for a detailed list of Byzantine authors who wrote on the topic of Muhammad's presumed fraudulence and disease), 132-3; C. Mango and R. Scott, eds, The Chronicle of Theophanes Confessor: Byzantine and Near Eastern History AD 284-813, Oxford, 1997, pp. 464-5; Johannes Damaskenos und Theodor Abū Qurra: Schriften zum Islam, eds R. Glei and A.T. Khoury, Würzburg et al., 1995, pp. 98-9. 
is invariably depicted as a lecher and an epileptic, who abused his fits to prove that he was receiving Divine revelations. In the same manner he allegedly fabricated 'miracles' in order to deceive the good people of Mecca. For instance, Muhammad was supposed to have trained a white dove to pick grains from his ears, pretending that the Holy Ghost had descended on him to whisper God's Word into his ear. In fact the people of Mecca could hardly have known what the Holy Ghost was, but in the eyes of European readers, who regarded Muhammad and his followers as Christian heretics rather than pagans, this made perfect sense. Muhammad also trained an ox to eat from his hand and run to him whenever it heard him speak. Between the horns of the ox Muhammad tied a copy of the Qur'an, and whenever he was preaching his travesty of Christianity the ox would push his way through the crowd with a Qur'an on its head: another miracle. Again, this is an elementary mistake, because both orthodox Muslims and western Orientalists agree that the Qur'an had not yet been codified in the days of the Prophet. Muhammad even managed to continue his 'tricks' after his death: he ordered a metal coffin for himself, and inside the 'church' where he was to be buried he concealed very strong magnets in the dome. After his death his body was taken to the church and the metal coffin rose to the ceiling, where it remained suspended in the air: yet another miracle and another proof of Islam (Figure 1.3) $\cdot{ }^{19}$ According to this Dutch popular treatise, in which all 'miracles' are duly repeated, the credulity of the Meccans was caused by the Devil: God had evidently turned his back on them, for those who enjoy His mercy would immediately have recognized it as a fraud. ${ }^{20}$ Remarkably, and perhaps uniquely, both editions of the book $(1627,1640)$ are enhanced by ten engraved illustrations of the Prophet, his life and his miracles, which are of course deeply offensive in Muslim eyes. ${ }^{21}$

19 On the false miracles of Muhammad see R.W. Southerner, Western Views of Islam in the Middle Ages, Cambridge, MA, 1962, pp. 28-33; J.V. Tolan, Saracens: Islam in the Medieval European Imagination, New York, 2002, pp. 137-47; id., Sons of Ishmael: Muslims through European Eyes in the Middle Ages, Gainesville etc., 2008, pp. 1-34; id., 'European accounts of Muhammad's life', in The Cambridge Companion to Muhammad, ed. J.E. Brockopp, Cambridge, 2010, pp. 226-50 (228-32).

20 [Anonymous], Historie van den Oorspronck, pp. 13-16, 21-32 [recte 23].

21 Apart from the frontispiece, which reproduces all the illustrations in reduced format, the 1627 edition of the Dutch treatise contains nine engravings of the life of the Prophet: [1] Muhammad as a child with his father and his Jewish mother (p. 2) - [2] The young Muhammad receiving instruction from a Jewish astronomer and the Christian monk Bahira/Sergius (p. 3) - [3] Evil omens announcing the birth of Muhammad (p. 6) - [4] The polygamist Muhammad in the company of three women (p. 8, this page lacking in the Leiden copy UBL 1144 A 46) - [5] Muhammad crowned King in Damascus (p. 11) - [6] 


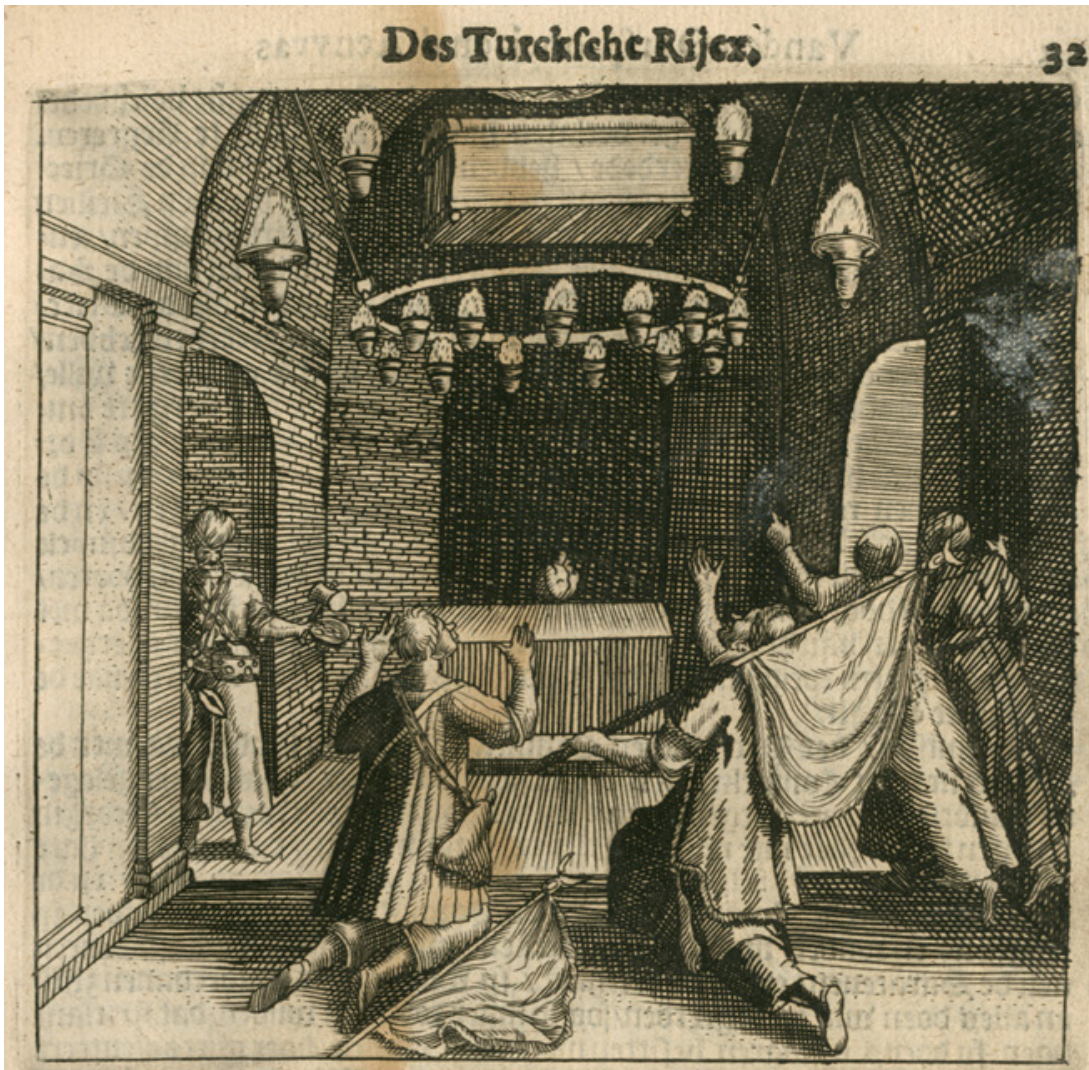

en tot bartnechighe Jiabametiften / upt d'upterfte entrepen ves MBerelta's oerwaertg te repfen / met fulchen moepte en arbept Dat het niet ts ghes Jabuents.

\section{Het XII, Capittel. Itan Othoman be tweede Coninck Det 5 a} racenen/,en Calyph d'eerte ban die naem.

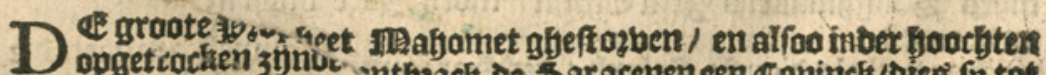

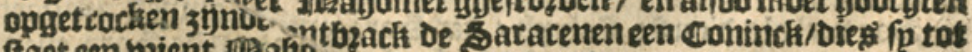

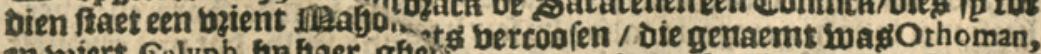

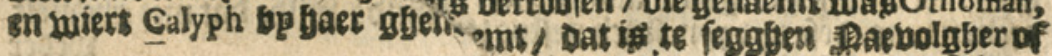
ervers

FIGURE 1.3 The coffin of the Prophet Muhammad miraculously floating in the air, in Anonymous, Historie van den Oorspronck ... des grooten valschen Propheets Mahomets, Leiden, 1627, p. 23. [LEIDEN UNIVERSITY LIBRARIES, 1144 A 46] 
However, this was not to remain an exception. Between 1657 and 1734 numerous editions appeared of Mahomets Alkoran, a retranslation of André Du Ryer's L'Alcoran de Mahomet (1647), which was not made by an academic but by a professional translator, Jan Hendrik Glazemaker (1620-1682). ${ }^{22}$ Glazemaker had no specific knowledge of Oriental languages or, for that matter, of Islam. All editions published from 1696 until 1734 contain six engravings by Casper Luyken (1672-1708). One illustration shows the Prophet as an epileptic, and another the Prophet with the dove and the bull. ${ }^{23}$

It is true that Dutch Arabists and Islam scholars have never been completely impervious to this approach of the Prophet and his Message. The legends of the white dove, the bull with the Qur'an between its horns and the floating coffin have never really struck root among Dutch academics, but the image of the Prophet Muhammad as a lecherous impostor and an epileptic has proved a tenacious survivor. In the mid-nineteenth century the Leiden professor Reinhart Dozy (1820-1883), an outspoken positivist and anti-clericalist, had recourse to modern medicine by describing the Prophet not as an epileptic but as an hysteric who was subject to frequent paroxysms. 'With these people', Dozy asserted, 'it is well nigh impossible to distinguish between self-delusion and fraud': ${ }^{24}$ Hysteria also served to explain the Prophet's presumed sensuality,

Muhammad in his epileptic convulsions (p. 13) - [7] Muhammad pretending to receive Divine revelations from a dove (p. 15) - [8] The ignominious death of Muhammad (p. 22) - [9] Muhammad's coffin floating in the air (p. 32 [recte 23]). There is no illustration in the book of the bull carrying the Qur'an, only in the frontispiece in reduced size.

On J.H. Glazemaker and his translation work see C.L. Thijssen-Schoute, 'Jan Hendrik Glazemaker de zeventiende-eeuwse aartsvertaler' in id., Uit de Republiek der Letteren: elf studiën op het gebied der ideeëngeschiedenis van de Gouden Eeuw, The Hague, 1967, pp. 206-61.

23 I used the last edition of Glazemaker's retranslation: Mahomets Alkoran, Door de Hr. Du Ryer uit d'Arabische in de Fransche Taal gestelt ... Alles van nieuws door J.H. Glasemaker vertaalt, en te zamen gebracht, Zynde den zevende en laatste Druk, met kopere Platen verciert, Leiden, 1734. For the engraving of the Prophet in an epileptic fit see facing p. 491, for the Prophet, the bull and the dove see facing p. 496. See also A. Hamilton and F. Richard, André Du Ryer and Oriental Studies in Seventeenth-Century France, London etc., 2004, pp. 114-16; A. Hamilton, 'The Quran in early modern Europe', in Oostersche weelde. De Oriënt in westerse kunst en cultuur ..., eds J. Schaeps et al., Leiden, 2005, pp. 131-43 (136-9); Id., The Forbidden Fruit: the Koran in Early Modern Europe, London, 2008, pp. 6-10; N. Klaversma and K. Hannema, Jan en Casper Luyken te boek gesteld: Catalogus van de boekencollectie Van Eeghen in het Amsterdams Historisch Museum, Hilversum, 1999, pp. 371-2, nn. 1048-53. 
and Dozy did not fail to point out that God had conveniently sent down a revelation which allowed him to marry Zaynab, the wife of his adopted son Zayd. ${ }^{25}$ In present-day public life a politician such as Geert Wilders, who is well known for his hostility to Islam, uses the same imagery and an average Dutch-language Google search with the terms 'Mohammed Wilders epilepsie' yields an astonishing 750,000 hits. ${ }^{26}$

\section{Dutch Arabists and the Dialogue with the Orient}

A rather more tolerant and even-handed approach of the Prophet Muhammad and his teachings, and of Arabic culture in general, can be detected in the works of many other Dutch Arabists from the early seventeenth century onwards. In 1611, for example, the young Thomas Erpenius was spending the summer in Conflans, a village not far from Paris. ${ }^{27}$ There he was working in relative solitude on his grammar of the Arabic language, which would make him famous throughout Europe. While in Conflans, an important Arab visitor called on him, the Spanish Muslim (morisco) Ahmmad b. Qāsim al-Ḥajarī. ${ }^{28} \mathrm{He}$ had fled from Spain in 1599 and made for Morocco, where he became a secretary and interpreter in the service of the sultan. In 1611 he travelled to Paris for diplomatic negotiations with the king of France. This was a windfall for Erpenius, who had never before met a native speaker of Arabic with a firm command of the classical language, and who had to derive all his knowledge from books. The Moorish scholar was sympathetic towards the young Dutchman and most likely helped him with the fine points of Arabic grammar. It was inevitable that they would come to discuss their respective religions. Erpenius, who had read the Qur'an and knew about its commentaries, tried to

\footnotetext{
25 Dozy, Het Islamisme, pp. 50-51.

26 A Google search carried out on 13 March 2015 with the Dutch terms 'Wilders Mohammed epilepsie' yielded c. 754,00o hits; a second search on the same day with the English terms 'Muhammad epilepsy' produced c. 361,00o hits.

27 On Thomas Erpenius see Juynboll, Beoefenaars, pp. 59-118; Vrolijk and Van Leeuwen, Arabic Studies, pp. 31-40.

28 On al-Ḥajarī see J.R. Jones, Learning Arabic in Renaissance Europe, 1505-1624, PhD dissertation, School of Oriental and African Studies, University of London, 1988, pp. 98-120; G.A. Wiegers, A Learned Muslim Acquaintance of Erpenius and Golius: Aḥmad b. Kâsim al-Andalusī and Arabic Studies in the Netherlands, Leiden, 1988, pp. 45-63; Ahmad b. Qāsim al-Ḥajarī, Kitāb nāṣir al-dīn 'alā al-qawm al-kāfirīn = The Supporter of Religion against the Infidels, eds P.S. van Koningsveld, Q. al-Samarrai and G.A. Wiegers, Madrid, 1997; Vrolijk and Van Leeuwen, Arabic Studies, pp. 32-3, 38.
} 
prove that Christians were right and Muslims wrong. To his surprise, al-Hajarī was not impressed and countered his arguments with great flair. Irritated, but with an undertone of respect, Erpenius wrote to Isaac Casaubon in London that 'the errors of the Muslims are not as easy to refute as many like to think.' ${ }^{29}$

In the summer of 1612 Erpenius returned to Leiden and a year later, in May 1613, he accepted his nomination as the first professor of Arabic in Leiden with his oration on the Excellence and Dignity of the Arabic Language. In June 1613, when he was preparing his Arabic grammar for the press, he suddenly received a letter from the same Aḥmad b. Qāsim al-Ḥajarī, who was in Amsterdam, waiting for a ship to take him home to Morocco. The Muslim scholar spent the whole summer in Leiden as a guest of Erpenius, and probably helped him again with his grammar. Their exchange of ideas must therefore have led to a certain degree of friendship, or at least mutual respect for their opinions.

In 1627 , the year of the popular anti-Islamic treatise mentioned above, the Arabist Jacobus Golius was staying in Aleppo as a secretary of the local Dutch consul. As he had done before in Morocco, Golius got in touch with local scholars who could assist him in his quest for texts. If he could not get hold of the originals he had them copied by scholars or scribes. One of these was a certain Darwīsh Aḥmad b. Ḥusām al-Gulshanī, a 'dervish' or brother of the Gülşeniye order of Sufis. For Golius he copied the Arabic translation of the Conica, a text on conic sections by the Greek-speaking scholar Apollonius of Perga. The dervish could indeed write Arabic, but he was not able to tackle the mathematical drawings. Hence Golius added them himself in a somewhat unsteady hand. The manuscript is thus a silent witness of the cooperation between a Dutch Arabist and a Muslim. ${ }^{30}$

An example from the Early Enlightenment is the eighteenth-century Arabist and Islam scholar Adriaan Reland (1676-1718), professor of Oriental languages in Utrecht. ${ }^{31}$ In 1705 he published a book about Islam, Dereligione Mohammedica, in which he debunked the medieval myths about Islam and called for a rational approach. This was an entirely new phenomenon in a country where

29 Thomas Erpenius to Isaac Casaubon, 4 Kal. Oct. $=28$ September 1611: 'sed, crede mihi, non sunt quidam eorum errores tam faciles confutatu, ut multi sibi imaginantur', in I. Casaubon, Epistolae, insertis ad easdem responsionibus, quotquot hactenus reperiri potuerunt, secundum seriem temporum accurate digestae, ed. T. Jansonius ab Almeloveen, 3rd edn, Rotterdam, 1709, Ep. 38, pp. 660-61.

30 On Golius's manuscript collections, public and private, see J.J. Witkam, Jacobus Golius (1596-1667) en zijn handschriften, Leiden, 1980; Vrolijk and Van Leeuwen, Arabic Studies, pp. $42-3$.

31 On Adriaan Reland see Nat, Studie, pp. 11-21; Vrolijk and Van Leeuwen, Arabic Studies, pp. $65^{-72}$. 
Glazemaker's Qur'an retranslation with its illustrations of an epileptic Prophet was still readily available. An enlarged edition appeared in 1717 , which was translated into Dutch (1718) and French (1721) (Figure 1.4). ${ }^{32}$ In his foreword to the second edition Reland expressed his desire to describe the 'Mohammedan Religion' as it really is, free of the many misconceptions which prevail in Europe. He realized that he was thus exposing himself to the criticism that he was too benevolent in his approach to the Muslims. Nevertheless, 'the truth, wherever it is, must be sought out'. In the case of a religion which is so widespread it is necessary 'to show [it to] anyone, not tarnished or covered with the fumes of calumny or errors, but as it is taught in the churches and schools of the Mohammedans'. ${ }^{33}$ But Reland hastened to add that such a reliable description was not intended as propaganda for Islam but to make men better equipped to combat Islam. According to Reland, the realization that Islam is an erroneous creed is no reason to regard the Muslims themselves as evil. Islam has retained many customs and principles which are comparable to Christian ones. This alone should help us reject the idea that in Islam 'nothing is clean and everything polluted. ${ }^{34}$ In Reland's eyes, a knowledge of Arabic was indispensable for a sound understanding of Islam. Some people think that the study of Arabic is valueless since Muslims are not prepared to discuss their religion and since 'it is hardly worthwhile (so many say) to endure the distress of looking into the vanities and fanaticism of a madman or someone possessed.' But, says Reland, 'Mohammedans are not as mad or possessed as we should like to think. Sound understanding is distributed equally among mankind. ${ }^{35}$ Hitherto

32 A. Reland, De religione Mohammedica libri duo, editio altera aucta, Utrecht, 1717; id., Verhandeling van de godsdienst der Mahometaanen, als mede van het krygs-regt by haar ten tyde van oorlog tegens de christenen gebruykelyk, Utrecht, 1718; id., La religion des Mahometans, exposée par leurs propres docteurs ..., The Hague, 1721. For the present contribution I have used the French translation.

Reland, La religion, p. cxiii: 'Non, il faut chercher la Verité par tout où elle est; ce sera toujours une entreprise louable de fermer la porte au Mensonge, de quel côté qu'il vienne, en éxposant aux yeux du Public une Religion d'une si vaste étenduë, non travestie, ou envelopée des nuages de la Médisance et de l'Erreur, mais telle qu'elle est enseignée, dans les Temples et dans les Ecoles des Mahométans.'

34 Ibid., p. cxxiii: 'comme si, en effet, il n'y avoit rien d'entier dans toute leur Doctrine; rien qui ne fût impur; rien qui ne fût plus sale que l'ordure meme.'

Ibid., pp. cxxiv-cxxv: 'C'est-à-dire, autant que je le puis conclurre, des discours qui m'en reviennent, que la chose n'en vaut pas la peine, qu'on n'a que faire de se donner tant de sueurs, ni de dévorer tant d'épines, pour apprendre des bagatelles, des niaiseries, les delires ridicules d'un Fanatique, qui avoit l'esprit en écharpe! [...] Mais, en vérité, les Mahométans n'extravaguent pas si fort que nous le prétendons: Le bon sens est de tous les Païs \& de tous les Climats $[\ldots] . '$ 

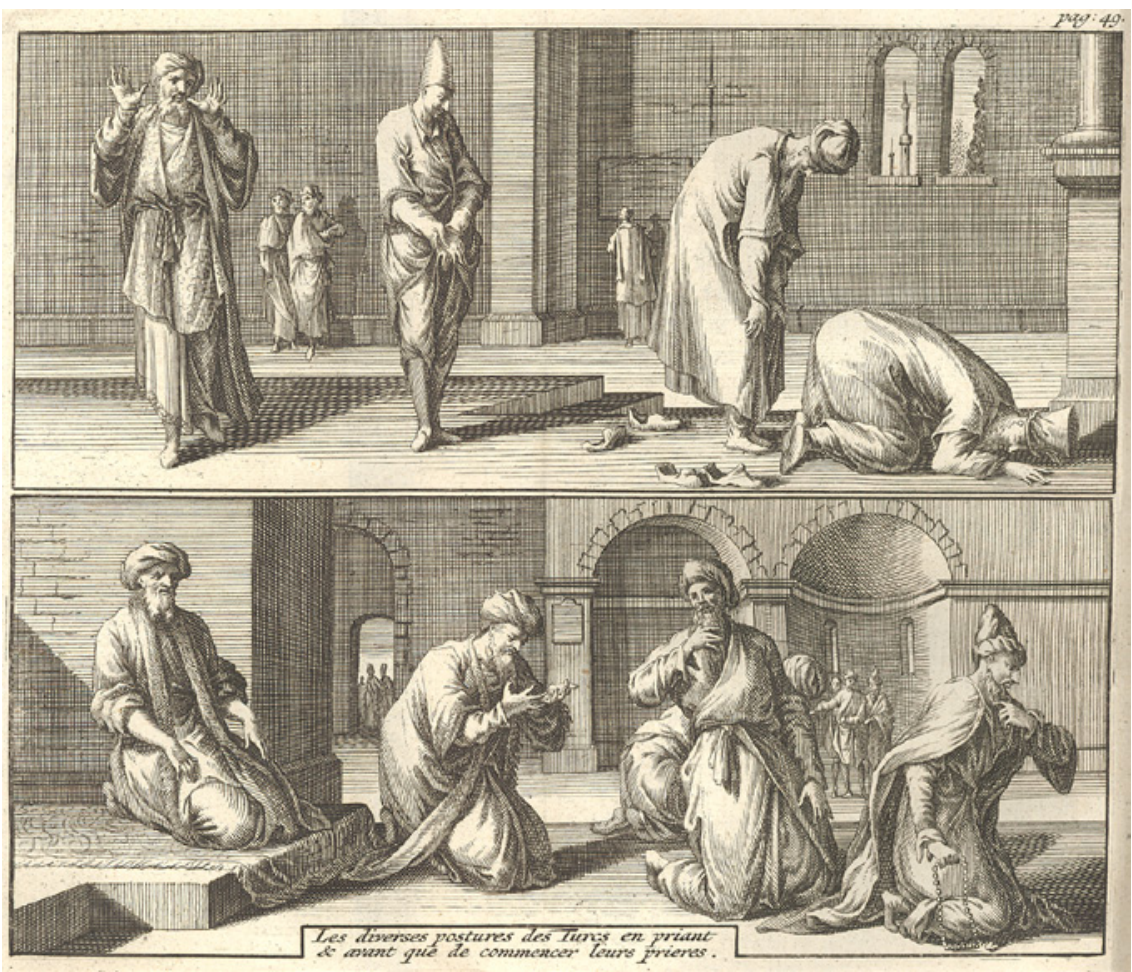

FIGURE 1.4 'Les diverses postures des Turcs en priant', illustrating 'Turks' during prayer in Adriaan Reland (1676-1718), La religion des Mahometans ..., The Hague, 1721, facing p. 49. [LEIDEN UNIVERSITY LIBRARIES, $409 \mathrm{~F}$ 5]

most polemicists 'did not combat the Mohammedan faith but their own illusions and shadows'. ${ }^{36}$

Yet in Reland's time there was still a long way to go from a rational acceptance of Arabs and their religion to an emotional one. In Academe this would only happen in the late eighteenth century, in the period of Early Romanticism. This was particularly late, for the general educated Dutch public had already embraced the image of the mysterious, exotic and erotic Orient in the early eighteenth century, when the first translation appeared of the Arabian Nights. Indeed, Antoine Galland's French translation only just preceded a pirate edition from The Hague. The first Dutch scholar who adopted the approach of the educated bourgeoisie was Hendrik Albert Schultens (1749-1793), the grandson

${ }_{36}$ Ibid., p. clv: 'la plûpart de tous ces Ecrivains, qu'on éxalte si fort, ont moins combattu la Religion Mahométane, que leurs propres phantomes.' 
of the redoubtable Albert Schultens. ${ }^{37}$ In ${ }^{1772-1773}$ he travelled to England, where he met not only David Garrick in his Theatre Royal, but also the British Orientalist William Jones (1746-1794). Jones was to have a deep and lasting influence on Schultens, which is reflected in his Verhandeling over de dichtkunde der Oosterlingen ('Discourse on the Poetry of the Easterners'), a lecture which Schultens delivered in 1776 before the Amsterdam society 'Concordia et Libertate'. It must have been an appreciative audience, eager to be informed about all sorts of exotic matters. Schultens admired the easterners for their 'common sense, genius and good taste.' ${ }^{38}$ It was above all the nomadic Arabs who had a great power of imagination and a great longing for freedom, the conditions for every good poet. According to Hendrik Albert Schultens this was because of the climatic extremities. 'Bare and burning deserts; hideous wildernesses; and arid sandy soil languishing with thirst' ${ }^{39} \mathrm{He}$ rejected the charge that eastern poetry is characterized by 'an uneven style, fake ingenuity and overblown rhetoric'. 40 The westerner must first transfer himself into the natural condition of the easterner before pronouncing himself. The young Schultens quoted abundantly from an Arab love poem:

\section{$[\ldots]$}

In this courtyard my Maya came to me

My Maya, whose brilliant sheen deadened that of the moon

Maya came to me and we gave ourselves over to love

I saw cheeks which put the softest roses to shame

I saw a neck, as white as lilies, as smooth as the most polished stones

Her jet black hair flowed over her shoulders

Her plaits were like palm clusters which, hanging from the trees, delighted our eyes

Her breast - Her hands - Her feet

The most modest of men can but be inflamed by the sight of such an extraordinary beauty

I plucked Maya by her enchanting plaits

She came to me

She threw herself on my bosom ${ }^{41}$

37 On H.A. Schultens see Nat, Studie, pp. 88-99; Vrolijk and Van Leeuwen, Arabic Studies, pp. 83-9.

$38 \quad$ H.A. Schultens, 'Verhandeling over de dichtkunde der Oosterlingen', in Drie redevoeringen van Hendrik Albert Schultens, ed. C.J. Wenckebach, Leeuwarden, 1845, pp. 1-42 (2).

39 Ibid., pp. 5-9.

$40 \quad$ Ibid., p. 35 .

41 Ibid., pp. 19-20: '[...] In dezen hof kwam mijne Maja bij mij / Mijne Maja, welker luisterrijke glans die der Maan verdooft / Maja kwam bij mij, en wij gaven ons geheel aan de 
It is a very free translation and the name Maya does not appear in the Arabic text, but that can hardly have mattered to the audience. It is not only a romantic approach, but also a sentimental one, because Schultens never went to the Middle East. He was never exposed to the barren climate he so eloquently described and he never saw an Arab at close quarters.

Even the nineteenth-century philologist Michael Jan de Goeje, who believed that Arabic geographical texts could help colonize Africa, let himself be inspired by the Arabs and their culture. He placed Islam next to Christianity and Judaism as the 'three noblest religions. ${ }^{42} \mathrm{He}$ was also genuinely moved by the beauty of Arabic poetry: 'The Arab people have produced masterpieces which are capable of bringing the strings which sounded in the poet's mind into movement in our own breasts too'. ${ }^{3} \mathrm{He}$ also believed in the future of the Arab world. Over sixty years before the foundation of Saudi Arabia he predicted that the Wahhabis in the Arabian Peninsula would found a kingdom on the ruins of the Ottoman Empire. According to him North Africa would 'not remain for ever the prey of foreign rule. Thus, without actually mentioning him by name, he was directly contradicting the influential French Orientalist Ernest Renan who, in his Histoire générale et système comparé des langues sémitiques of 1854 , had maintained that the world of Islam had no future. ${ }^{44}$

liefde over / Ik zag wangen, die de zachtste rozen beschamen / Ik zag eenen hals, blank als de leliën, glad als de meest gepolijste steenen / Hare gitzwarte haren golfden over hare schouders / Hare vlechten waren als de palmtrossen, die van de boomen neerhangende onze oogen bekoorden / Hare borst - Hare handen - Hare voeten / De ingetogenste mensch moest op 't gezigt van zulk een zeldzame schoonheid geheel ontvlammen / Ik tokkelde Maja bij die bekoorlijke vlechten / Zij kwam bij mij / Zij wierp zich op mijnen boezem [...].' Schultens quoted loosely from a poem in S.H. Manger's edition of Ibn 'Arabshāh's Vitae et rerum gestarum Timuri ... historia, Franeker, 1767, p. 426 and following; Vrolijk and Van Leeuwen, Arabic Studies, p. 84.

42 De Goeje, De belangrijkheid, p. 4: 'De drie edelste godsdiensten'.

43 Ibid., p. 10: 'Daarin heeft het Arabische volk meesterstukken voortgebracht, die in staat zijn de snaren, welke in het gemoed des dichters trilden, ook in onze borst in beweging te brengen.'

44 Ibid., p. 22; Vrolijk and Van Leeuwen, Arabic Studies, pp.110-11. For an assessment of Renan's views on the world of Islam see J. Fück, Die arabischen Studien in Europa bis in den Anfang des 20.Jahrhunderts, Leipzig, 1955, p. 201; E. Said, Orientalism, repr. with a new afterword, Harmondsworth, 1995, pp. 130-48; R. Irwin, For Lust of Knowing: The Orientalists and their Enemies, paperback edn, London, 2007, pp. 168-9. 


\section{Conclusion}

With these examples I have tried to illustrate my point that many Dutch Arabists have opened their minds, and sometimes also their hearts, to the Arabs, their language, culture and religions. In this respect it would indeed appear that knowledge breeds understanding. But at the same time Dutch Arabists have never been able to escape from the constraints of their own scholarly culture or the material conditions imposed by their own society. As such, Arabic studies in the Netherlands have always been, and still are, more about the Netherlands than the Arab world. 